Arch. histol. jap., Vol. 40, Suppl. (1977)

p. $207-219$

Department of Anatomy (Prof. T. Yамамото), Faculty of Medicine, Kyushu University,

Fukuoka, Japan

\title{
Neuro-Epithelial Bodies in the Lung of the Rat and the Mouse
}

\author{
Kōjiro Wasano
}

\begin{abstract}
Summary. Histochemical and ultrastructural examinations were performed on neuroepithelial bodies (N. E. B.) in the lung of the mouse and rat. The N. E. B. were identified as specialized groups of pale, columnar cells. They were located throughout the intrapulmonary airway. These cells displayed some special cytochemical properties also seen in the APUD (Amine Precursors Uptake and Decarboxylation) endocrine system, such as cytoplasmic argyrophilia and the capability of selective uptake of amine precursors. Ultrastructurally the $\mathbf{N}$. E. B. were composed of a kind of granulated cell which had concentrations of specific cored vesicles in the basal cytoplasm. It seemed likely that the cells released the contents of the cored vesicles into the extracellular space by exocytosis. These cells made extensive and intimate contact with the mitochondria-rich nerve terminals which occurred mainly at the level of the supranuclear portions of the granulated cells. In this contact area, the membrane of the nerve terminals were apposed to that of the granulated cells with a consistent gap of about $20 \mathrm{~nm}$. Among these membrane appositions, some membrane thickenings were observed in which cored vesicles were closely associated in the granulated cell cytoplasm. From these observations, it was conceived that the lung N.E. B. function both as receptor and endocrine organs and that their specific cored vesicles may have an intimate correlation with these dual functions.
\end{abstract}

It has been reported that specialized epithelial cells are present in mammalian respiratory passages which are different in fine structure and cytochemical properties from the ordinary epithelial cells (LAUwERYNs et al., 1972; ERICson et al., 1972; HuNG et al., 1973; HAGE et al., 1974; Cutz et al., 1974, 1975). These cells are known to occur either singly (ERICSON et al., 1972; CUTZ et al., 1975) or in clusters (LAUWERYNS et al., 1972; CUTZ et al., 1974) and are suggested to be member of the APUD cell series (PEARse, 1969).

Rich innervation in cluster occurring APUD cells which are confined to the intrapulmonary airways led some authors (LAuweryns et al., 1972; HunG et al., 1973) to suggest that the APUD cells should be referred to as neuro-epithelial bodies (N. E. B.) and that they may function both as receptor and endocrine organs. The functional significance of the N. E. B. in the lung, however, remains unclear.

The present study was carried out to obtain more detailed morphological informations on the N.E.B. and to obtain some clues to clarify the functional implications of these structures.

\section{Materials and Methods}

Ten young adult mice and eight young adult rats were used in this study. The thorax was opened under slight anesthesia by intraperitoneal injection of Nembutal; then, the lung was removed and cut into small blocks.

For light microscopy, the materials were fixed either in Bouin's fixative, 6\% glutaraldehyde or glutaraldehyde-picric acid solution for $24 \mathrm{hrs}$. After dehydration in graded ethanol, specimens were embedded in paraffin, and $10 \mu \mathrm{m}$ sections were made. Grimelius' method variant I (Grimelius, 1968) was applied on Bouin-fixed 
materials, SinGH's argentaffin method (SINGH, 1964) on 6\% glutaraldehyde-fixed samples, and HCL-toluidine blue method (Solcia et al., 1968) on glutaraldehyde-picric acid-fixed specimens. As controls, the duodenum and the pancreas were prepared as above.

Some materials were prepared according to Falck's fluorescent amine technique (FALCK et al., 1962). Prior to tissue preparation, each animal was intraperitoneally administrated a single injection of either L-dopa or L-5HTP dissolved in saline solution $(100 \mathrm{mg} / \mathrm{kg}$ body weight). Control animals were injected only with saline solution. Animals were sacrificed $30 \mathrm{~min}$ after injection, and small pieces of the lung were immediately frozen in isopentane cooled with liquid nitrogen, freeze-dried in Edward's freeze-drying apparatus at $-60^{\circ} \mathrm{C}$ for 2 days, and exposed to formaldehyde gas (relative humidity $50 \%$ ) at $80^{\circ} \mathrm{C}$ for $1 \mathrm{hr}$. Then the materials were embedded in filtered paraffin, and sections ( $8 \mu \mathrm{m}$ thick) were mounted in liquid paraffin and examined in a Olympus fluorescence microscope equipped with a mercury lamp USH$202 \mathrm{~A}, \mathrm{~B}_{1}, \mathrm{~B}_{2}$ activating filters and $\mathrm{Y}-50$ barrier filter.

For electron microscopy, the small specimens of the lung from four mice were degassed in a plastic injector containing $3 \%$ glutaraldehyde buffered with $0.1 \mathrm{M}$ cacodylate at $\mathrm{pH} 7.4$ until they sank. They were then transferred into the same fixative for an additional $2 \mathrm{hrs}$, and postfixed in $1 \% \mathrm{OsO}_{4}$ solution buffered with $0.1 \mathrm{M}$ cacodylate at $\mathrm{pH} 7.4$ for $1 \mathrm{hr}$. The specimens were then dehydrated in graded ethanol, and embedded in epoxy resin.

Thick sections for light microscopy were cut on a Porter-Blum microtome and stained with toluidine blue. When N. E. B. were found in these sections, the blocks were carefully trimmed, and ultrathin sections were cut with glass knives on a Porter-Blum microtome and stained with lead citrate. These sections were examined in a Hitachi HU-12A electron microscope.

\section{Light microscopy}

\section{Results}

The N. E. B. were observed to be specialized cell groups composed of tightly packed columnar cells occurring throughout the mucosa of the intrapulmonary airways, especially at the bifurcation of the air duct (Fig. 1, 5). Each cell of the N. E. B. rested on the basement membrane, exposed its narrow apex to the airway lumen and was characterized by a pale cytoplasm and an elongated nucleus. Five to twenty cells were located in each N. E. B. The cells in the proximal N. E. B. were somewhat fewer in number and taller in height than those of the distal ones.

After GRIMELiUs' reaction, the cells composing the N. E. B. of rat showed a prominent argyrophilia in the basal portion of cytoplasm. In addition, some meandering nerve fibers, impregnated simultaneously, ran toward the base of the N. E. B. from the underlying connective tissue, and appeared to enter the N. E. B. (Fig. 2).

Other staining methods applied in this study, argentaffin reaction and $\mathrm{HCl}$-toluidine blue staining, gave negative results in the N. E. B. of the lung of the rat and mouse.

\section{Fluorescence microscopy}

In the control animals, mast cells and nerve fibers showed yellow and green fluorescence respectively, but the cells of the N. E. B. did not show any fluorescence. 


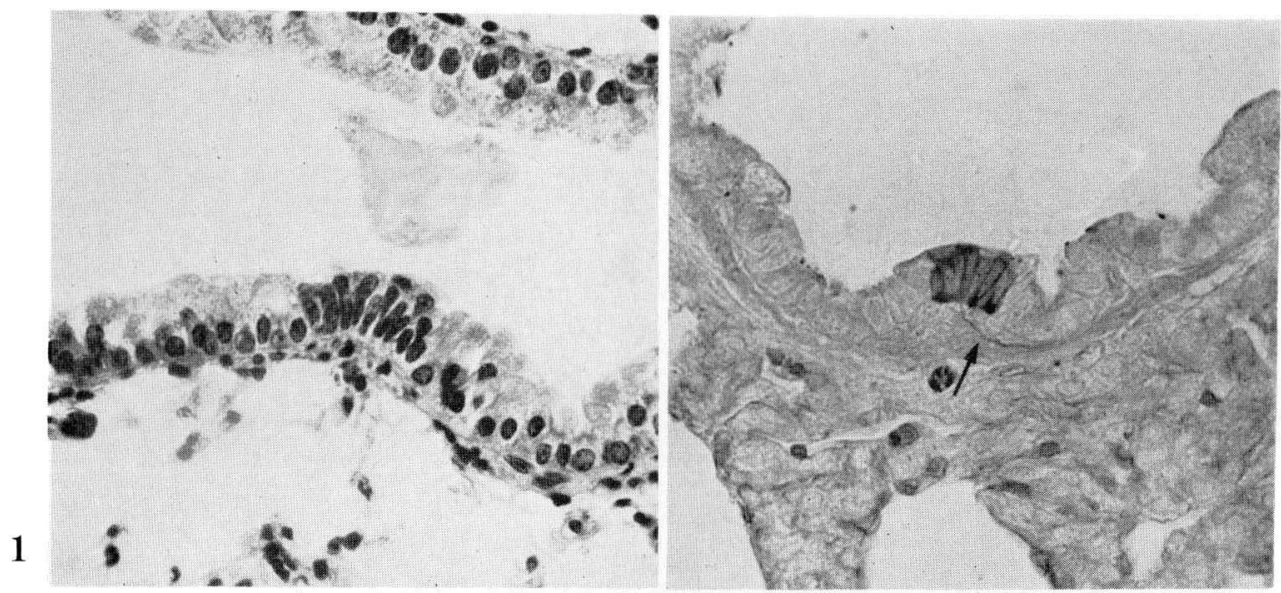

Fig. 1. A neuro-epithelial body in the bronchial epithelium of the mouse. It is easily distinguished from the ordinary bronchial epithelium as tightly packed columnar cell group. H. E. $\times 150$

Fig. 2. A neuro-epithelial body showing positive argyrophilia in the bronchial epithelium of the rat. Note the silver impregnated nerve fiber in the lamina propria running toward the base of the N. E. B. (arrow). Grimelius' silver method. $\times 150$
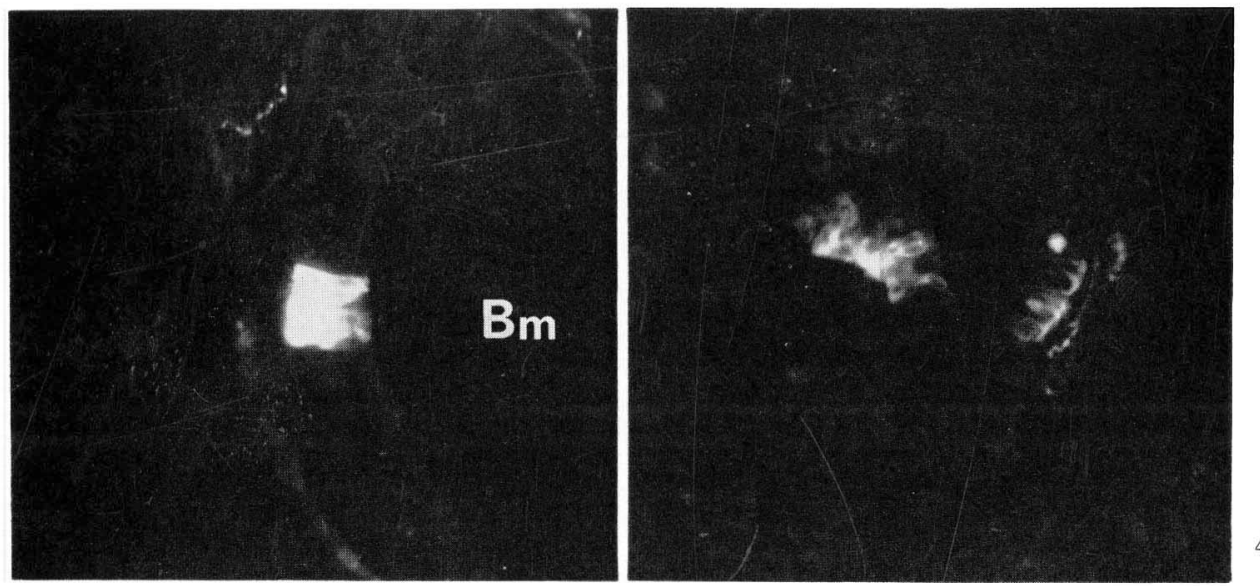

Fig. 3. Neuro-epithelial body emitting green fluorescence after administration of L-dopa. Beaded nerve fiber can be seen at the middle upper part of this micrograph. Bm bronchiolar lumen. FalcK's method. $\times 150$

Fig. 4. Neuro-epithelial body exhibiting yellow fluorescence after 5-HTP treatment. This N. E. B. was larger in cell number and located in a more distal bronchiole than the N. E. B. shown in Figure 3. FALCK's method. $\times 150$

When treated with amine precursors, however, the N. E. B. cells emitted intense fluorescences which were yellow with 5HTP and green with L-dopa (Fig. 3, 4).

\section{Electron microscopy}

The N. E. B. consisted of a kind of granulated cell which was always found in groups and associated with intraepithelial nerve fibers. Some blood capillaries 


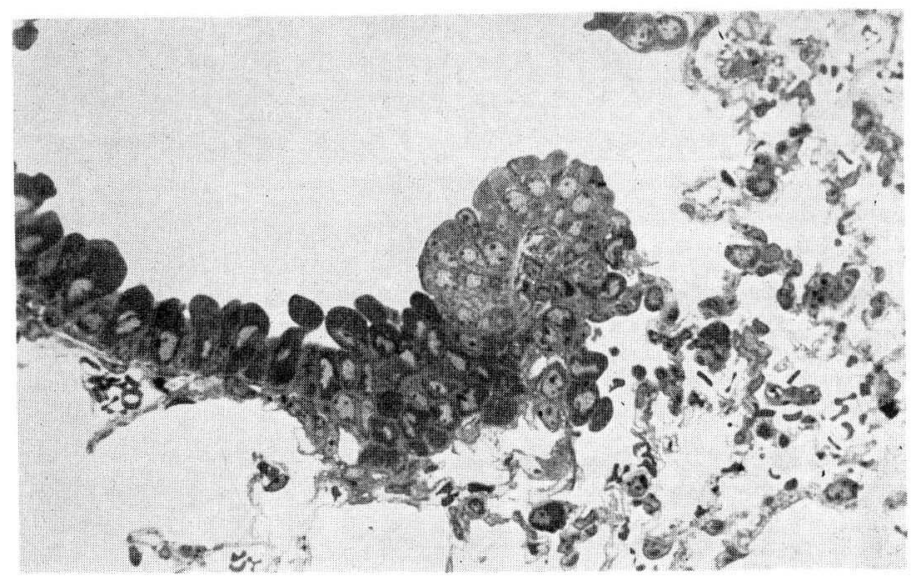

Fig. 5. Neuro-epithelial body located at the margin of the distal bronchiole. The cells forming the N. E. B. were easily distinguished from adjacent Clara cells with their low cytoplasmic density. Epon embedded section stained with toluidine blue. $\times 150$

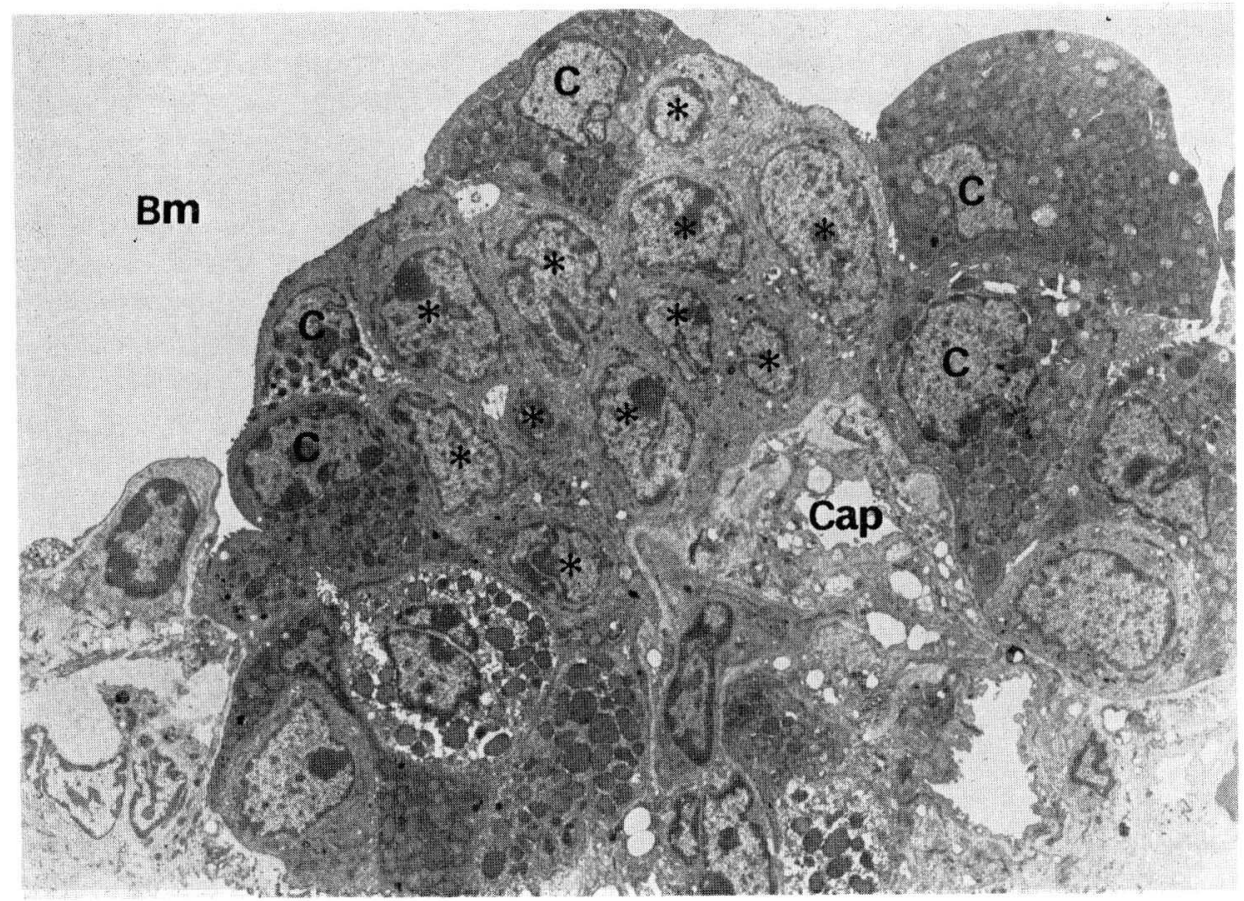

Fig. 6. Low magnification electron micrograph of the N. E. B. of mouse. Eleven granulated cells were distinguishable (*). $\quad C$ Clara cell, Cap capillary, Bm bronchiolar lumen. $\quad \times 2,400$ 
were located in the underlying connective tissue of the N. E. B. (Fig. 6, 10).

The granulated cells: The granulated cells rested on the basement membrane. A few short microvilli were observed on the luminal surface of the cells. A junctional complex was observed between adjacent granulated cells or between granulated cells and surrounding epithelial cells. Occasionally a single cilium was observed projecting into the intercellular space (Fig. 7). A large nucleus with deep indentations occupied the middle portion of the cell body.

Small elongated mitochondria and a number of free ribosomes were dispersed throughout the cytoplasm. Bundles of filaments oriented along the longitudinal axis of the granulated cell were present especially in the perinuclear cytoplasm (Fig. 8, 12). Rough surfaced endoplasmic reticulum was rather well developed in the apical portion of the cytoplasm. A few lysosomes and clear vacuo'es were present in the basal cytoplasm (Fig. 8, 9); the well-developed Golgi apparatus which was often associated with the cored vesicles was located in the supranuclear cytoplasm (Fig. 12).

The most characteristic feature of these cells was the occurrence of many cored vesicles, particularly in the basal cytoplasm (Fig. 8, 9). These vesicles were about $100 \mathrm{~nm}$ in diameter and had a light halo around the core. Although the core materials seemed to show some variations in electron opacity, size and texture, it was difficult to classify them clearly into subgroups. The limiting membrane of some cored vesicles fused with the basal cell membrane to become small caveole, indicating the possible release of their contents into the extracellular space by exocytosis (Fig. 9). Besides such exocytotic invaginations, many coated pits were observed on the basal cell membrane and free coated vesicles in the basal cytoplasm of the granulated cells (Fig. 9).

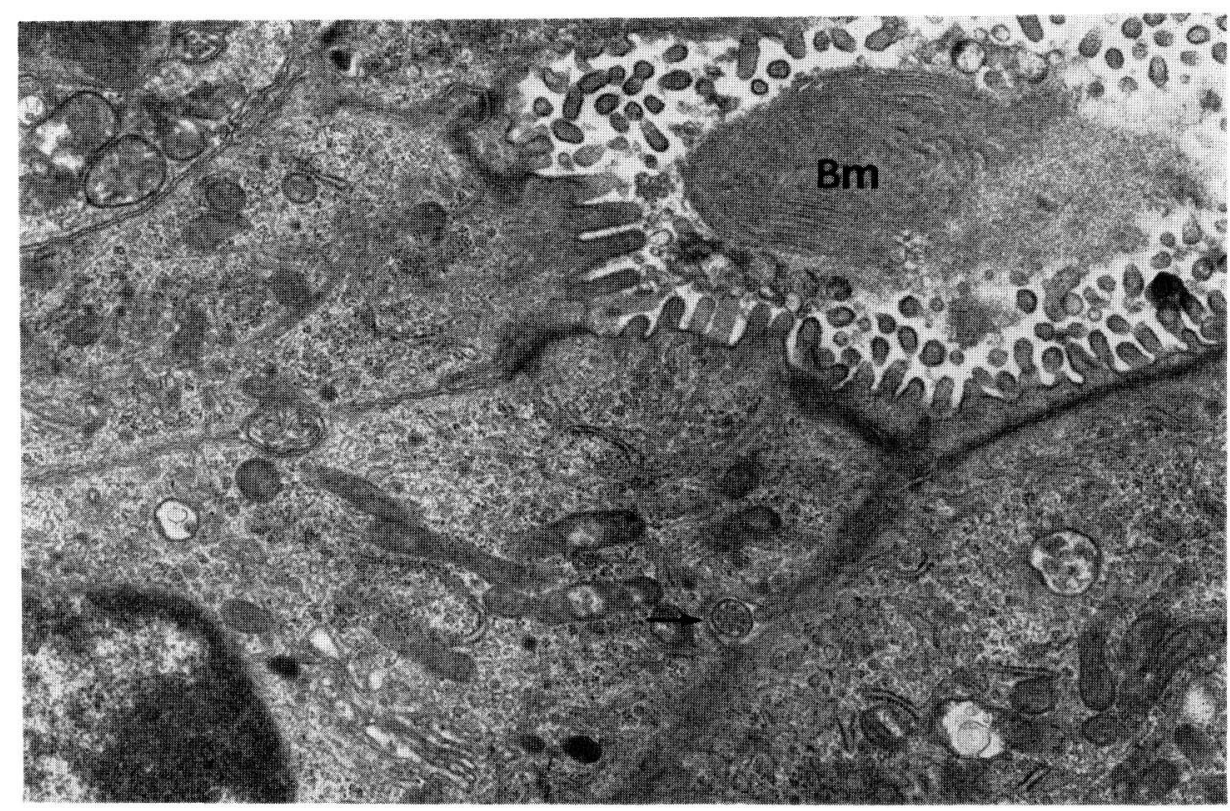

Fig. 7. Apical portions of the granulated cells in the N. E. B. facing the lumen (Bm) with a few short microvilli. A single cilium is seen in the intercellular space (arrow). $\times 16,000$ 
The nerve and its relationship to the granulated cells: The nerve fibers lost their covering of Schwann cells in the underlying connective tissue, then, penetrated the basement membrane of the epithelium and entered into the intercellular space of the N. E. B. (Fig. 11). These nerve fibers possessed an electron-lucent axoplasm which contained a few clear vesicles, myelinated figures, mitochondria, neurotubuli and neurofibrils. They showed several beaded varicosities packed with numerous mitochondria. Most of these varicosities were found in the intercellular space at the

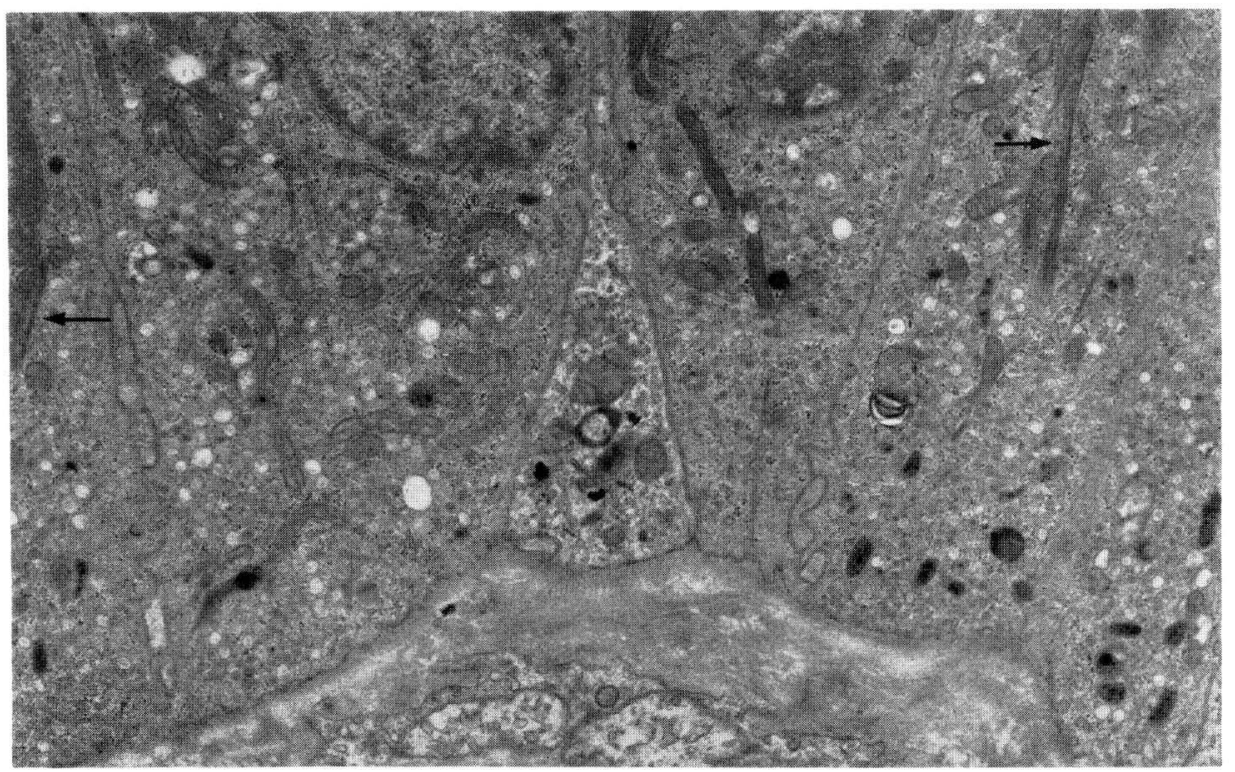

Fig. 8. Basal parts of the granulated cells contained numerous cored vesicles intermingled with a few lysosomes and large clear vacuoles. The bundles of cytoplasmic filaments run in parallel with the longitudinal axis of the cell (arrows). $\times 10,000$

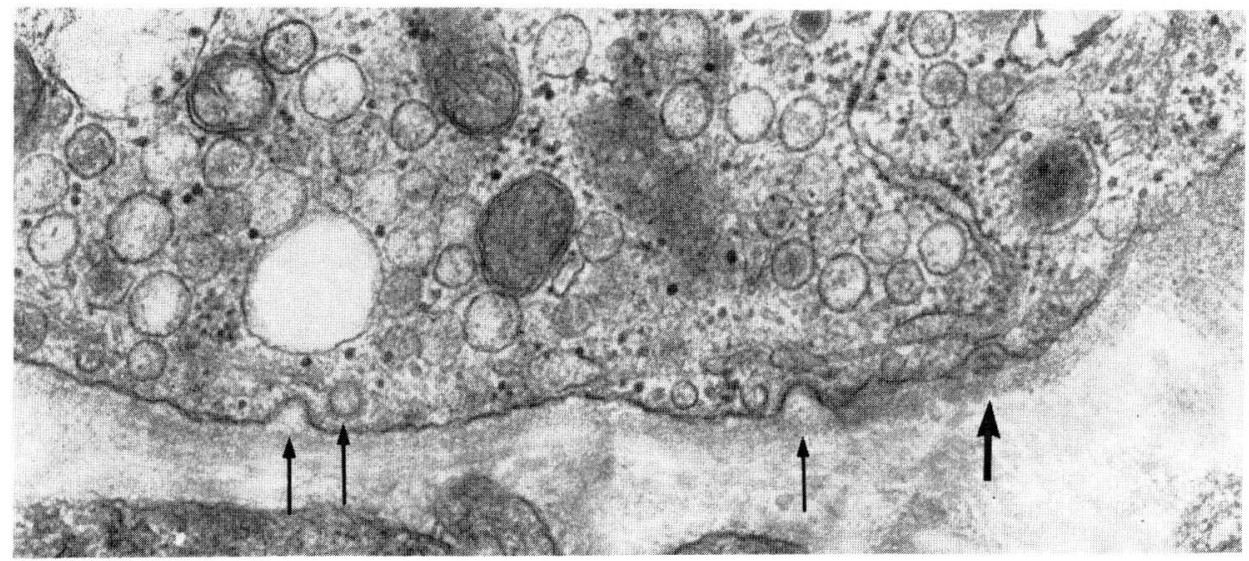

Fig. 9. Higher magnification electron micrograph of the basal part of the granulated cell showing the release of the cored vesicle by exocytosis (large arrow). Several coated pits and free coated vesicles (small arrows) are also seen. $\times 20,000$ 

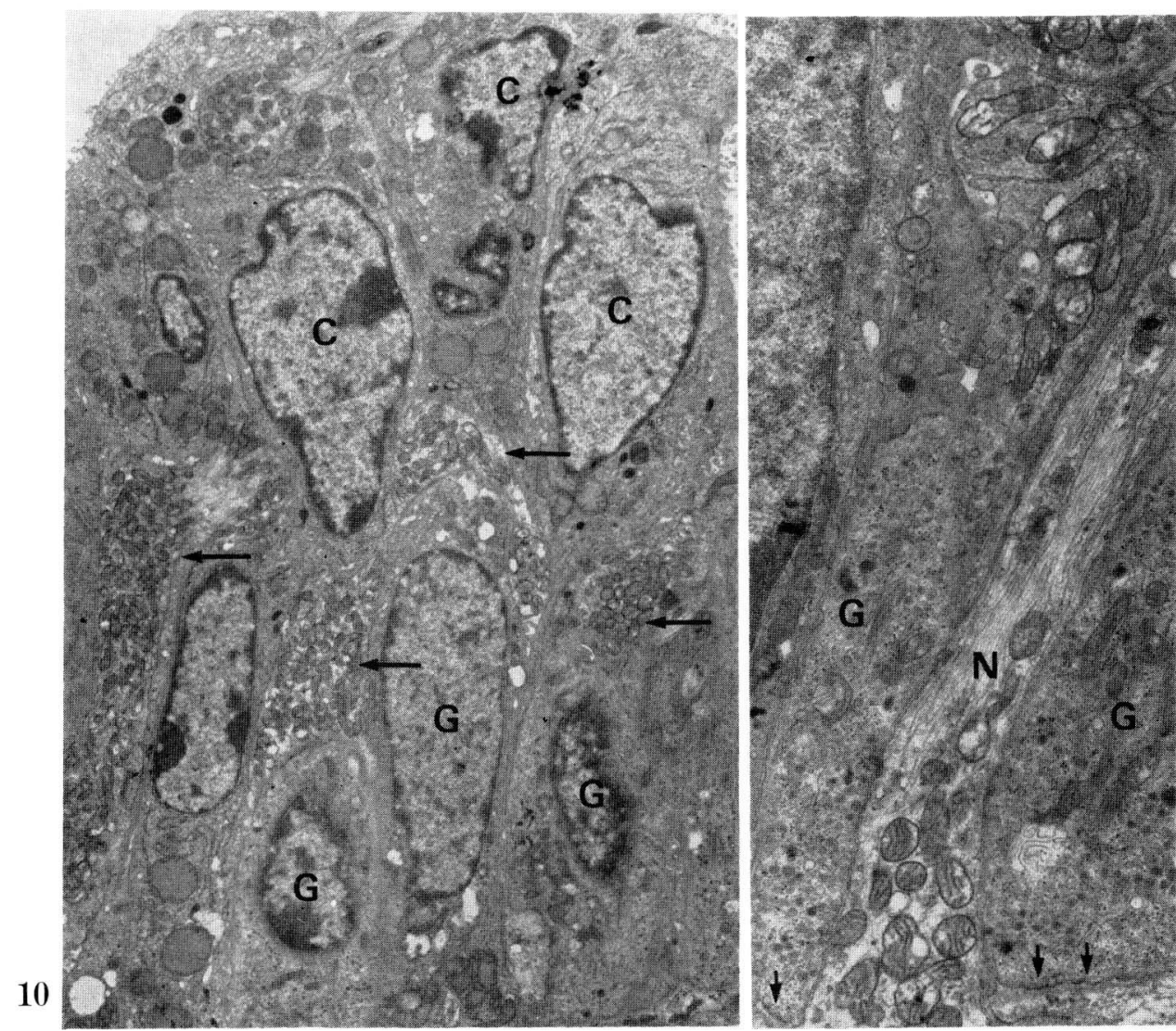

Fig. 10. The N. E. B. with abundant innervation (arrows) at the supranuclear portion of the granulated cells $(G) . \quad C$ Clara cell. $\times 4,000$

Fig. 11. The nerve fiber $(N)$ in the intercellular space of the N. E. B. contains small clear vesicles, myelinated figures, mitochondria, neurotubuli and neurofibrils penetrating the basement membrane (small arrows). G granulated cell. $\times 11,000$

level of the supranuclear portion of the granulated cells. An intervening gap of about $20 \mathrm{~nm}$ in width separated the varicosities and the granulated cell (Fig. 10, 12). The membrane thickenings of both granulated cells and nerve endings were observed in several places along contact areas. There cored vesicles were in close association in the cytoplasm of the granulated cell, indicating the formation of synaptic contacts between the granulated cells and the nerve endings (Fig. 13).

\section{Discussion}

\section{Granulated cells in the lung N. E. B. as APUD cells}

Amine precursor uptake and decarboxylation is known to be a principal cytochemical criterion of the APUD cell series (PEArse, 1969; Owman et al., 1973). Fluorogenic amines could not be demonstrated in the bronchial epithelium of the untreated mouse and rat. After administration of amine precursors, a group of the fluorescent 


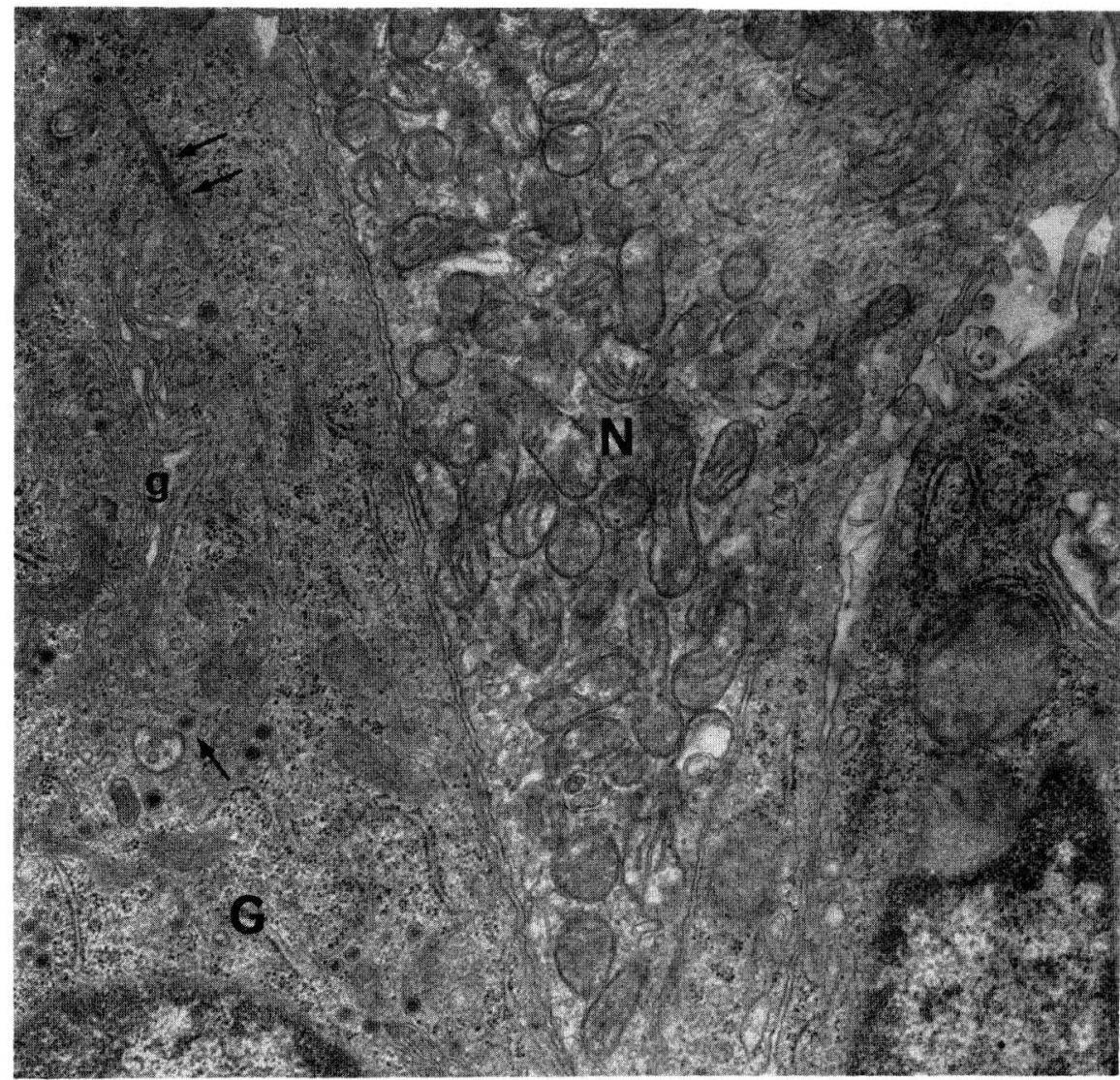

Fig. 12. The supranuclear portion of the granulated cells $(G)$ in contact with the enlarged nerve endings $(N)$ containing numerous mitochondria and some clear vesicles. Well-developed Golgi complexes $(g)$ associated with a few cored vesicles (arrow) and bundles of filaments (double arrows) are also seen. $\times 22,000$

cells appeared in the bronchial epithelium of both animals. This indicates that the cells have a capacity of taking up and synthesizing amines upon administration of amine precursors. LAUWERYNS and his co-workers (1972) have demonstrated the primary existence of serotonin in the N. E. B. of the rabbit lung and speculated that serotonin might correspond to the humoral factor suggested by some physiologists (Maeye, 1965; Lloyd, 1968; Hauge, 1969); this factor induces pulmonary venous constriction under hypoxia. In the present study, however, the primary amine content could not be demonstrated in murine lungs. This absence of amines in murine lung N.E. B. was previously reported by ERICSON and his co-workers (1971) using the monoamine oxidase inhibitor, nialamid. The reason for the variability in the occurrence of amines in different species is still unknown. However, not only endogenous amines but also amines formed after administration of the precursors are known to be stored in the secretary granules (ERICsOn et al., 1971; LauWEryns et al., 1972). This intimate structural relationship between the amines and the granules might suggest that there is also a functional relationship between the amines and the granules. In 


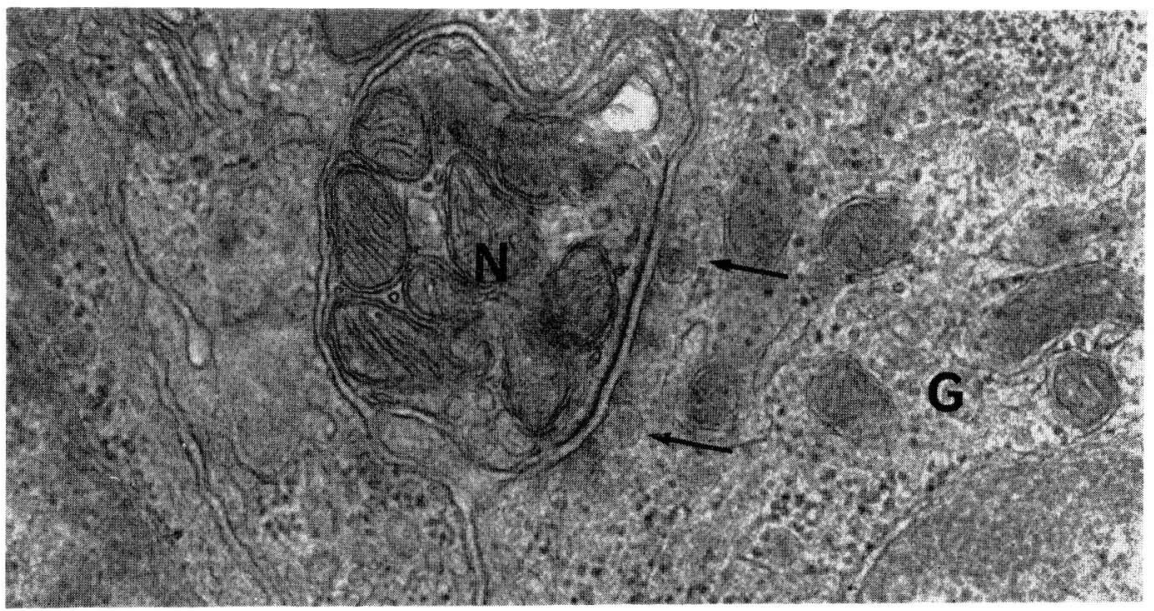

Fig. 13. The membrane specialization at the contact area between the granulated cell $(G)$ and nerve ending $(N)$. Several cored vesicles are in clcse contact with the presynaptic granulated cell membrane (arrows). $\times 40,000$

fact, data published by PEARSE (1966) and LINDQUIST and his co-workers (1971) suggested that the amines play an important cytophysiological role in formation, storage or release of the hormones in the APUD endocrine cell.

Grimelius' argyrophilia is known to be another characteristic feature of the APUD cell series (HAKAnson et al., 1971). Cells revealed by fluorescence microscopy to have similar features and localizations showed prominent argyrophilia after Grimelius' reaction in the rat but not in the mouse. Such species difference was already reported by HAGE (1974). She examined the lungs of various mammals including mouse, guinea-pig, rabbit, human fetus and human adult and found that the cells of the rabbit and human lung were positive in silver reaction and the others were negative. Such a difference in affinity to silver might imply some difference in the nature of the secretory granules, since Grimelius' silver is believed to be related to some component of the endocrine cell granules (VASSALLo et al., 1971).

The granulated cells of the N. E. B. were characterized by abundant cytoplasmic vesicles with cores. These vesicles were primarily located in the basal cytoplasm. It was noticed that some cored vesicles release their contents into the underlying connective tissue by exocytosis. Free coated vesicles and large vacuoles were frequently seen in the basal cytoplasm. These membranous structures might be involved in a membrane retrieving mechanism which functions after exocytotic granule release as reported by NaGAsawA and Douglas (1972) in the adrenal medulla, and by KoBayashi and Sasagawa (1976) in the gut endocrine cells. Thus, all the cytochemical and fine structural features of the granulated cells of the lung N. E. B. as revealed by cytochemical and electron microscopic methods are in keeping with the idea that they belong to the APUD series proposed by PEARSE.

According to PEARSE's hypothesis, all the members of the APUD series produce their own polypeptide hormone(s). Therefore, it follows that the granulated cells in the lung N.E. B. should elaborate and release specific polypeptide hormone(s). On this subject, attention might be given to certain vasoactive peptides recently isolated from 
porcine lungs by SAID and his co-workers (1972), and by KITAmURA and his co-workers (1973). These peptides show biochemical and physiological natures similar to the VIP (Vasoactive Intestinal Peptide) isolated from the gastro-intestinal tract by SAID and MutT (1970). Hence, they are called VLP (Vasoactive Lung Peptides) (SAID et al., 1972). These pulmonary peptides have not been fully purified, though their tracheobronchial-relaxant activities as well as vasodilative actions have been demonstrated (Kitamura et al., 1973; SAID et al., 1974).

Although their exact physiological roles and cellular sources remain unclear, it may be possible to speculate that the granulated cells of the N. E. B. are the sources of these polypeptides (or hormones) and that they participate in the humoral and local mechanisms regulating the ventilatory and circulatory flow-dynamics of the lung by reacting to adequate stimuli, most probably inspired gas content changes as suggested by LAROS (1971).

\section{Granulated cells in the lung N. E. B. as sensory cells}

The granulated cells in the N. E. B. were also characterized by having close contact with the intraepithelial nerve endings packed with numerous mitochondria. A similar type of nerve ending was observed in other organs such as the muscle spindle (Adal, 1969), the taste bud (Murray and Murray, 1967), the carotid body (VERNA, 1973) and the mechanoreceptor in the skin (CAUNA, 1966; NisHi et al., 1969; IGGo and MUIR, 1969); they are now regarded as sensory in nature. It is striking that the granulated cells in the N. E. B in the bronchial epithelium contain cytoplasmic granules similar to those in the chief cells in the carotid body and those in the Merkel cells of the skin.

The results of the present study seem to support the view that the N.E. B. functions as a sensory receptor unit in the lung. The N. E. B. might correspond to the hypothetic receptor called "Lung Irritant Receptor" suggested by SELLICK and WIDDICOMBE (1969) and Mills and his co-workers (1972) based on the result of their physiological studies. It is proposed that the "Lung Irritant Receptors" are located within the bronchial epithelium and stimulated by various chemical and mechanical stimuli (SEllick and Widdicombe, 1969; Mills et al., 1972).

According to a quantitative study on the intraepithelial nerves in rat airways (JEFFREY and REID, 1973), the N. E. B. are selectively innervated, whereas ordinary epithelial cells receive no intraepithelial innervations. This observation might imply an intimate functional relationship between the granulated cells and the nerve endings as a receptor unit. In this connection, it is noteworthy that the rabbit N. E. B. cells increased their granule secretion at the synaptic contact areas with nerve endings during experimental exposure to hypoxia (LAUweryns and CoKELEARE, 1973). In the N.E. B. of the mouse lung, however, membrane specialization has not yet been observed (Hung et al., 1973).

In the present study, synaptic membrane specializations were for the first time demonstrated between granulated cells and nerve endings. Furthermore, cored vesicles were frequently found to be in close contact with the presynaptic membrane of the granulated cells. It seems likely that those cored vesicles in the vicinity of the presynaptic membrane are synaptic vesicles in function and contain a transmitter.

Then, what is the chemical nature of the transmitter? According to the hypothesis proposed by WINKLER and his co-workers (1972) and KoBAYASHI and SASAGawA 
(1976) the cored vesicles in all the members of PEARSE's APUD series contain not only amines but also adenine nucleotides, polypeptides, proteins and metal ions. It may be worthy of mention that most of these substances can be considered as neuro-transmitter candidates (Burnstock, 1972; Agranoff, 1975; Otsuka et al., 1975; BRyAnt et al., 1976). In analogy with other APUD cells, the granulated cells in the N. E. B. should contain amines, adenine nucleotides, peptides and metal ions in the cored vesicles. However, further studies are needed to know the exact chemical nature of the transmitter specific to the granulated cells.

\title{
ネズミ肺の神経上皮複合体に関する組織化学的ならびに 電子顕微鏡的研究
}

\author{
和佐野 公二郎
}

成熟マウスおよびラットの肺の神経上皮複合体 (N. E. B.) に関して観察を行なった.

1. パラフィン切片，へマトキシリン・エオシン染色標本においては， N. E. B. は肺内 気道上皮内，特に気道分岐部近傍に 特殊な細胞集団として識別される．2. GRIMELIUS 法 (1968)によって，ラットの N. E. B. は好銀性を示す. 3. N. E. B. はアミン前駆物質の 投与によってアミンの特異螢光を発することが観察される. したがって N.E.B.を構成す る細胞は，いわゆる APUD 細胞群 (PEARSE, 1969)に属する. 4. 電顕的には N.E. B. は基 底部に多数の芯あり果粒を持つ果粒細胞と, ミトコンドリアを多数含んだ上皮内神経終末 とによって構成されている. 上皮内神経終末は, 果粒細胞の核上部の細胞膜と緊密に接す

る. 5. 基底細胞膜には芯あり果粒の開口分泌がみられた. 一方，これらの芯あり果粒の 付着を伴った果粒細胞膜と神経終末間のシナプス様の膜分化がしばしば認められた。

以上の観察により, ネズミ肺の神経上皮複合体は, 内分泌機能と同時に知覚受容器とし ての機能を持つこと, および 果粒細胞の特殊な芯あり果粒が この両機能に密接に関連し ていることが推定された。

\section{References}

Adal, M. N.: The fine structure of the sensory region of cat muscle spindles. J. Ultrastr. Res. 26: 332-354 (1969).

Agranoff, B. W.: Neurotransmitters. Neurotransmitter and synaptic transmission. Fed. Proc. 34: 1911-1914 (1975).

Bryant, M. G., S. R. Bloom, J. M. Polak, R.H. Albuquerque, I. Modlin and A. G. E. Pearse : Possible dual role for vasoactive intestinal polypeptide as gastrointestinal hormone and neurotransmitter substance. Lancet 7967: 991-993 (1976).

Burnstock, G.: Purinergic nerves. Pharmacol. Rev. 24: 509-581 (1972).

Cauna, N.: Fine structure of receptor organs and its probable functional significance. In: Touch, heat and pain. Churchill, London, 1966. 
Cutz, E., W. Chan, V. Wong and P. E. Conen : Endocrine cells in rat fetal lung. Lab. Invest. 30: 458-464 (1974).

-: Ultrastructure and fluorescence histochemistry of endocrine (APUD type) cells in tracheal mucosa of human and various animal species. Cell Tiss. Res. 158: 425-437 (1975).

Ericson, L. E., R. Hakånson, B. Larson, CH. Owman and F. Sundler: Fluorescence and electron microscopy of amine-storing enterochromaffin-like cells in tracheal epithelium of mouse. Z. Zellforsch. 124: 532-545 (1972).

Falck, B., N. A. Hillarp, G. Tieme and A. Torp: Fluorescence of catechol amines and related compounds condensed with formaldehyde. J. Histochem. Cytochem. 10: 348-354 (1962)

Grimelius, L.: A silver nitrate stain for $\alpha_{2}$ cell in human pancreatic islets. Acta Soc. Med. Upsal. 73: $243-270$ (1968).

Hage, E.: Histochemistry and fine structure of endocrine cells in fetal lungs of the rabbit, mouse and guinea-pig. Cell Tiss. Res. 149: 513-524 (1974).

Hakånson, R., C. Owman, B. Sporrong and F. Sundler: Electron microscopic classification of amine-producing endocrine cells by selective staining of ultrathin sections. Histochemie 27: 226-242 (1971).

Hauge, A.: Hypoxia and pulmonary vascular resistance. The relative effects of pulmonary arterial and alveolar $\mathrm{PO}_{2}$. Acta physiol. scand. 76: 121-130 (1969).

Hung, K. S., M. S. Hertweck, J. D. Hardy and C. G. Loosli : Ultrastructure of nerves and associated cells in bronchial epithelium of the mouse lung. J. Ultrastr. Res. 43: 426-437 (1973).

Iggo, A. and A. R. Muir: The structure and function of a slowly adapting touch corpuscles in hairly skin. J. Physiol. 200: 763-796 (1969).

Jeff rey, $\mathbf{P}$. and L. Reid : Intra-epithelial nerves in normal rat airways: a quantitative electron microscopic study. J. Anat. 114: 35-45 (1973).

Kitamura, S., S. I. Said, L. D. Holden, R. W. Merrill and W. T. Ford: Newly extracted polypeptides as bronchodilators and pulmonary vasodilators (abstr.). Clin. Res. 21: 100 (1973).

Kobayashi, S. and T. Sasagawa: Morphological aspect of the secretion of gastro-enteric hormones. In: (ed. by) T. Fujita: Endocrine gut and pancreas. Elsevier, Amsterdam-New York, 1976. (p. 255-271).

Larros, C. D.: Local chemical regulation of flow resistance in the bronchial tree and pulmonary circulation. Respiration 28: 120-136 (1971).

Lauweryns, J. M. and M. Cokeleare: Hypoxia-sensitive neuro-epithelial bodies intrapulmonary secretary neuroreceptor, modulated by the CNS. Z. Zellforsch. 145: 521-540 (1973).

Lauweryns, J. M., M. Cokeleare and P. Thenynck: Neuro-epithelial bodies in the respiratory mucosa of various mammals: a light optical, histochemical and ultrastructural investigation. Z. Zellforsch. 135: 569-592 (1972).

Lindquist, I., R. Ekholm and L. E. Ericson : Monoamine in the pancreatic islets of the mouse, 5-hydroxytryptamine as an intracellular modifier of insulin secretion, and the hypoglycemic action of monoamine oxidase inhibitors. Diabetologia 7: 414-422 (1971).

Lloyd, T. C. J. : Hypoxic pulmonary vasoconstriction; role of perivascular tissue. J. appl. Physiol. 25: 521-540 (1973).

Mills, J. E., H. Sellick and J. G. Widdicombe : Activity of lung irritant receptors in pulmonary micro-embolism, anaphylaxis and drug induced bronchoconstrictions. J. Physiol. (London) 203: 337-357 (1969).

Murray, R. G. and A. Murray : Fine structure of taste bud of rabbit foliate papillae. J. Ultrastr. Res. 19: 327- 353 (1967).

Naeye, R. L.: Pulmonary vascular changes with chronic unilateral pulmonary hypoxia. Circulation Res. 17: 160-197 (1965).

Nagasawa, J. and W. W. Douglas: Thorium dioxide uptake into adrenal medullary cells and the problem of recapture membrane following exocytosis. Brain Res. 37: 141-145 (1972). 
Nishi, K., C. Y. Oura and W. Palline: Fine structure of Pacinian corpuscles in the mesentery of the cat. J. Cell Biol. 43: 539-552 (1969).

Otsuka, M., S. Konishi and T. Takahashi : Hypothalamic substance P as a candidate for transmitter of primary afferent neurons. Fed. Proc. 34: 1922-1928 (1975).

Owman, C., R. Hakånson and F. Sundler: Occurrence and function of amines in endocrine cells producing polypeptide hormones. Fed. Proc. 32: 1758-1791 (1973).

Pearse, A. G. E. : $\quad$-HTP uptake by dog thyroid C cells, and its possible significance in polypeptide hormone production. Nature 211: 598-600 (1966).

- : The cytochemistry and ultrastructure of polypeptide hormone producing cells of the A. P. U. D. series and the embryologic, physiologic and pathological implications of the concept. J. Histochem. Cytochem. 17: 303-313 (1969).

Said, S. I., S. Kitamura and V. Mutt : Biologically active polypeptide from the lung. In: (ed. by) J. Meienhofer: Chemistry and biology peptides. Ann Arbor Science Poblishers, Ann Arbor, Mich, 1972 (p. 409-414).

Said, S. I., S. Kitamura and T. Yoshida: Humoral control of airway. Ann. N. Y. Acad. Sci 221: 103-114 (1974).

Said, S. I. and V. Mutt: Polypeptide with broad biological activity: isolation from small intestine. Science 169: 1217-1218 (1970).

Sellick, H. and J. G. Widdicombe: The activity of lung irritant receptor during pneumothorax, hyperpnoea and pulmonary vascular congestion. J. Physiol. (London) 203: 359-381 (1969).

Singh, I.: A modification of the Masson-Hamperl method for staining of argentaffin cells. Anat. Anz. 115: 81-82 (1964).

Solcia, E., G. Vassallo and C. Capella : Selective staining of endocrine cells by basic dyes after acid hydrolysis. Stain Technol. 43: 257-263 (1968).

Vassallo, G., C. Capella and E. Solcia: Grimelius' silver stain for endocrine cell granules, as shown by electron microscopy. Stain Technol. 46: 7-13 (1971).

Verna, A.: Terminaisons nerveuses afférentes et efférentes dans le glomus carotidien du Lapin. J. Microsc. 16: 299-308 (1973).

Winkler, H., J. A. L. Schöpf, H. Hörtnagl and H. Hörtnagl : Bovine adrenal medulla: Subcellular distribution of newly synthesized catecholamines, nucleotides and chromogranins. Arch. exp. pathol. Pharmakol. 273: 43-61 (1972).

和佐野 公二郎

T814 福岡市東区馬出 3 丁目 1-1

九州大学医学部

解剖学第 1 講座
Dr. Kōjiro Wasano

Department of Anatomy

Kyushu University School of Medicine

Fukuoka, 814 Japan 